Pobrane z czasopisma Annales H - Oeconomia http://oeconomia.annales.umcs.pl Data: 26/04/2023 10:28:17

DOI:10.17951/h.2018.52.1.49

\begin{tabular}{lc}
\hline \multicolumn{1}{c}{ A N N A L E S } \\
UNIVERSITATIS MARIAE CURIE-SKŁODOWSKA \\
LUBLIN - POLONIA \\
VOL. LII, 1 & SECTIO H \\
\hline
\end{tabular}

Uniwersytet Ekonomiczny we Wrocławiu. Wydział Zarządzania, Informatyki i Finansów

ALICJA GRZEŚKOWIAK

alicja.grzeskowiak@ue.wroc.pl

Polskie obszary metropolitalne a wybrane komponenty kapitatu
ludzkiego - analiza na podstawie samooceny kompetencji

Polish Metropolitan Areas and Selected Components of Human Capital:

Analysis Based on Self-Assessment of Competences

Słowa kluczowe: obszary metropolitalne; kapitał ludzki; kompetencje

Keywords: metropolitan areas; human capital; competences

Kod JEL: J24; O18; C19

\title{
Wstęp
}

Termin „obszary metropolitalne” nie posiada jednoznacznej definicji [zob. Lackowska, 2009, s. 23-31], choć jasne jest, że powstają one na skutek rozwoju miast i na ich strukturę składa się centrum (duże miasto) oraz strefa zewnętrzna (obszary przylegające lub powiązane funkcjonalnie), a wpływ obserwować można także w dalszej strefie oddziaływania [Nowak, 2010, s. 7-10]. Jednym z istotnych czynników wzmacniających funkcje metropolitalne jest kapitał ludzki [Pasterz, 2010].

Kapitał ludzki nie jest pojęciem precyzyjnym, ponieważ na jego treść składają się różne składniki, wśród których Pocztowski [2003, s. 45] wymienia wiedzę, umiejętności, zdrowie i motywację. Kapitał ludzki jako twór niematerialny jest trudny do zmierzenia, a jego wielowymiarowość powoduje, że stosowane są różne podejścia w jego ocenie, bazujące np. na miernikach edukacyjnych, dochodowych, kosztowych 
[Kryńska, Kwiatkowski, 2013, s. 158] oraz związanych z ochroną i stanem zdrowia, strukturą wykształcenia czy posiadaną wiedzą i umiejętnościami [Jabłoński, 2012, s. 103-119].

W niniejszym artykule rozpatrzono jeden z aspektów kapitału ludzkiego związany z zasobami kompetencyjnymi ludności Polski. Analizy przeprowadzono w oparciu o wyniki ogólnopolskich badań pt. „Bilans Kapitału Ludzkiego”, przeprowadzonych przez Polską Agencję Rozwoju Przedsiębiorczości i Uniwersytet Jagielloński ${ }^{1}$

Głównym celem pracy jest dokonanie oceny zasobów wybranych elementów kapitału ludzkiego w odniesieniu do obszarów metropolitalnych. Realizacji celu głównego zostały podporządkowane cele szczegółowe związane z dwutorowym porównaniem zasobów kompetencyjnych, powiązane z następującymi pytaniami badawczymi:

1. Czy istnieją różnice w poziomie kompetencji mieszkańców obszarów metropolitalnych i pozostałych jednostek terytorialnych?

2. Na ile różni się poziom kompetencji w miastach centralnych w porównaniu do pozostałych części obszarów metropolitalnych?

3. W jaki sposób można scharakteryzować występujące różnice?

Odpowiedzi na pytania badawcze poszukiwano, dokonując porównań przeciętnego poziomu kompetencji oraz stosując metodę wizualizacji w postaci wykresów asocjacji.

\section{Metodyka badania}

Wyodrębnianie obszarów o charakterze metropolitalnym może opierać się na różnych kryteriach, wśród których wskazać można następujące propozycje [Danielewicz, Markowski, 2008, za: Nowak, 2010]:

- według mierników mobilności ludności,

- na podstawie terytorialnych jednostek statystycznych NTS 3 (podregionów),

- zgodnie z deklaracją gmin i powiatów o przystąpieniu do obszaru,

- w oparciu o warunki społeczne, gospodarcze, przyrodnicze.

W niniejszej pracy przyjęto podział według drugiego z wymienionych podejść, które jest stosowane przez Unię Metropolii Polskich jako zbieżne z podziałem na regiony statystyczne Unii Europejskiej, co umożliwia dokonywanie ewaluacji i porównań niezbędnych w polityce spójności i konkurencyjności [Danielewicz, 2013, s. 93]. W skład Unii Metropolii Polskich wchodzi 12 miast: Białystok, Bydgoszcz, Gdańsk, Katowice, Kraków, Lublin, Łódź, Poznań, Rzeszów, Szczecin, Warszawa i Wrocław. Stanowią one centra obszarów metropolitalnych, wyodrębnionych zgodnie z podziałem NTS 3 i pokrywających się z regionami metropolitalnymi ustalonymi

1 Opis badania oraz jego wyniki są dostępne na stronie projektu: https://bkl.parp.gov.pl [dostęp: 10.02.2018]. 
przez Eurostat i Dyrekcję Generalną Komisji Europejskiej ds. Polityki Regionalnej i Miejskiej [Unia Metropolii Polskich, 2013, s. 3-4]. Położenie zdefiniowanych w ten sposób obszarów metropolitalnych wraz z ich miastami centralnymi zilustrowano na rys. 1 .

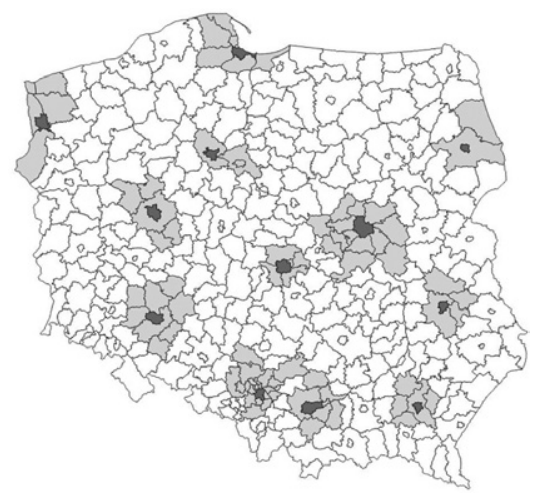

Rys. 1. Zasięg obszarów metropolitalnych i ich miasta centralne - delimitacja według Unii Metropolii Polskich

Źródło: opracowanie własne.

Analizy dotyczące różnic w zakresie elementów kapitału ludzkiego zostały wykonane na podstawie danych pochodzących z pięciu edycji badania „Bilans Kapitału Ludzkiego"2, które miały miejsce w latach 2010-2014, w ramach których zgromadzono odpowiedzi ponad 88,5 tys. respondentów wylosowanych spośród osób w wieku produkcyjnym zamieszkałych w Polsce. W ramach badania ankietowani dokonywali samooceny swoich umiejętności. Respondenci oceniali swoje kompetencje w pięciopunktowej skali, na której jedynką oznaczono najniższy poziom, a piątką - najwyższy. Kwestionariusz obejmował 12 głównych rodzajów kompetencji [PARP, 2013, s. 18-19]:

- wyszukiwanie i analiza informacji oraz wyciąganie wniosków,

- obsługa, montowanie i naprawa urządzeń technicznych,

- wykonywanie obliczeń,

- obsługa komputera i wykorzystanie internetu,

- zdolności artystyczne i twórcze,

- sprawność fizyczna,

- samoorganizacja pracy i przejawianie inicjatywy (rozplanowanie i terminowa realizacja działań w pracy, skuteczność w dążeniu do celu),

- kontakty z innymi ludźmi, zarówno ze współpracownikami, jak i klientami czy podopiecznymi,

- organizowanie i prowadzenie prac biurowych,

2 https://bkl.parp.gov.pl [dostęp: 10.02.2018]. 
- zdolności kierownicze i organizacja pracy innych,

- dyspozycyjność,

- biegłe posługiwanie się językiem polskim w mowie i piśmie (poprawność językowa, bogate słownictwo, łatwość wysławiania się).

Ze względu na długie nazwy kompetencji, w dalszej części pracy w tabelach i w formach graficznych użyto skrótów, odpowiednio: informacje, urządzenia, obliczenia, komputer, artystyczne, sprawność, inicjatywa, kontakty, organizowanie, kierowanie, dyspozycyjność, polski.

Należy zaznaczyć, że proponowane podejście badawcze zasadza się na samoocenie kompetencji dokonywanej przez respondentów, a więc jest oparte na subiektywnych przekonaniach ankietowanych. Takie ujęcie ma zasadniczą wadę - opinie podmiotów oceniających mogą być mocno rozbieżne względem obiektywnych sposobów pomiaru [Górniak (red.), 2014, s. 192]. Rzecz jasna dużo lepiej w celach porównawczych byłoby bazować na zobiektywizowanych wskaźnikach. Niestety, nie są prowadzone badania na tak szeroką skalę, dostarczające adekwatnych danych do wykonania tego typu analiz. Wobec braku zobiektywizowanej wiedzy o poziomie kompetencji wykorzystano dostępny materiał statystyczny odnoszący się do deklarowanych ocen, traktując go jako wartościowe źródło informacji służących porównaniom.

Analiza obejmuje dwa główne nurty: porównanie zasobów kompetencji deklarowanych przez mieszkańców obszarów metropolitalnych w odniesieniu do respondentów z pozostałych jednostek terytorialnych oraz ocenę różnic istniejących wewnątrz obszarów metropolitalnych w sensie zestawienia miast centralnych i ich otoczenia.

W celach porównawczych posłużono się średnimi wynikami dla uwzględnionych 12 obszarów kompetencji w ujęciu rozpatrywanych podziałów terytorialnych. Zidentyfikowano kategorie kompetencji, dla których różnice są największe i najmniejsze. Zweryfikowano hipotezy o równości przeciętnych wyników dla poszczególnych umiejętności, co pozwala na wyciągnięcie wniosków dotyczących zróżnicowania kapitału ludzkiego w kontekście przyciągania go przez obszary metropolitalne oraz ich miasta centralne.

Testowanie różnic dla średnich ma charakter bardzo ogólny - jeżeli są ku temu przesłanki, pozwala odrzucić hipotezę o ich równości, ale nie wskazuje, w czym można upatrywać źródła zróżnicowania. Dlatego w przypadku stwierdzenia występowania znacznych różnic zdecydowano o zastosowaniu bardziej szczegółowego podejścia, bazującego na tabelach kontyngencji uwzględniających ocenę kompetencji w skali 1-5 oraz określenie miejsca zamieszkania (obszary metropolitalne - pozostałe obszary lub miasta centralne - pozostałe części obszarów metropolitalnych). Ze względu na dużą liczbę rozpatrywanych umiejętności i konieczność dokonania wielu porównań zastosowano metodę wizualizacji, noszącą miano wykresu asocjacji (association plot), umożliwiającą szybką identyfikację komórek tabeli kontyngencji o największych odchyleniach wartości obserwowanych od oczekiwanych.

Wykres asocjacji został zaproponowany przez Cohena [1980], a jego dokładny opis można znaleźć w pracach Friendly [2000, s. 90], Friendly i Meyera [2015, 
s. 145], Meyera, Zeileisa i Hornika [2003]. Idea ilustracji jest związana z indywidualnym wkładem poszczególnych komórek tabeli w wartość statystyki chi-kwadrat, mierzony resztami Pearsona, który można wyrazić jako:

$$
c_{i j}=\frac{n_{i j}-n_{i j}{ }^{\prime}}{\sqrt{n_{i j}{ }^{\prime}}}
$$

gdzie:

$\mathrm{n}_{\mathrm{ij}}$ - liczebność obserwowana danej komórki

$\mathrm{n}_{\mathrm{ij}}$ - liczebność oczekiwana danej komórki tabeli

Przykładowa tabela kontyngencji i odpowiadający jej wykres asocjacji zostały zaprezentowane na rys. 2.

\begin{tabular}{|c|c|c|}
\hline \multirow{2}{*}{ Cecha X } & \multicolumn{2}{|c|}{ Cecha Y } \\
\cline { 2 - 3 } & 0 & 1 \\
\hline \multirow{2}{*}{1} & 39 & 5 \\
& $(34,922)$ & $(9,078)$ \\
\hline \multirow{2}{*}{2} & 362 & 42 \\
& $(320,645)$ & $(83,355)$ \\
\hline \multirow{2}{*}{3} & 555 & 113 \\
& $(530,176)$ & $(137,824)$ \\
\hline \multirow{2}{*}{4} & 525 & 225 \\
& $(595,257)$ & $(154,743)$ \\
\hline
\end{tabular}

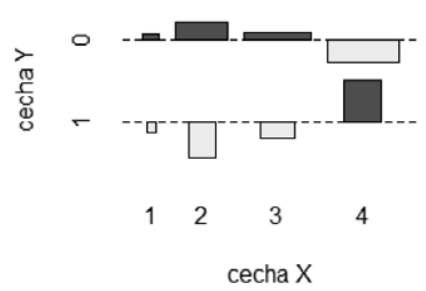

Rys. 2. Tabela kontyngencji z liczebnościami obserwowanymi i oczekiwanymi (w nawiasach) oraz odpowiadający jej wykres asocjacji

Źródło: opracowanie własne.

Poszczególne komórki tabeli są na wykresie reprezentowane za pomocą prostokątów zaczynających się na linii ilustrującej zerową wartość wyrażenia $n_{\mathrm{ij}}-n_{\mathrm{ij}}$. Jeżeli różnica $n_{\mathrm{ij}}-n_{\mathrm{ij}}$ jest dodatnia, to prostokąt jest zorientowany ku górze, jeżeli ujemna - ku dołowi. Dodatkowo, w celu podkreślenia kierunku odchylenia, stosuje się odmienną kolorystykę dla dodatnich i ujemnych różnic. Podstawa prostokąta jest proporcjonalna do pierwiastka $\mathrm{z}_{\mathrm{ij}}$, a jego wysokość - do całego wyrażenia $\mathrm{c}_{\mathrm{ij}}$. Stąd pole prostokąta odzwierciedla wielkość różnicy pomiędzy liczebnością obserwowaną a oczekiwaną, co pozwala na łatwe wyszukanie, które elementy tabeli kontyngencji charakteryzują się największymi odchyleniami. Z kolei na podstawie wysokości prostokątów można wnioskować, które komórki tabeli w znacznym stopniu wpływają na wartość statystyki chi-kwadrat. Przykładowo układ na rys. 2 pozwala stwierdzić, że najwyższe odchylenia mają miejsce dla wartości 4 dla cechy $\mathrm{X}$, a duże różnice pomiędzy liczebnościami obserwowanymi a oczekiwanymi występują także dla wartości 2. Natomiast oczekiwane liczebności wartości 1 dla cechy X są najniższe ze wszystkich kategorii. 


\section{Ocena różnic w zakresie kapitału ludzkiego pomiędzy obszarami metropolitalnymi a pozostalymi jednostkami terytorialnymi}

Na podstawie wyników badania „Bilans Kapitału Ludzkiego” obliczono przeciętne wartości samooceny kompetencji osób zamieszkujących obszary metropolitalne oraz pozostałe polskie podregiony i na poziomie istotności 0,001 zweryfikowano hipotezy o równości średnich. W tab. 1 zestawiono wyznaczone różnice w ewaluacji umiejętności w kolejności od największej do najmniejszej oraz wnioski płynące z testowania różnic. Badanie wykazało, że z wyjątkiem sprawności fizycznej wszystkie różnice mają istotny charakter. Należy podkreślić, że w każdej kategorii kompetencji istnieje przewaga obszarów metropolitalnych nad pozostałymi jednostkami terytorialnymi. Największe różnice odnotowano w przypadku umiejętności związanych z obsługą komputera i użytkowaniem internetu, organizowaniem i prowadzeniem prac biurowych oraz zdolnościami kierowniczymi i predyspozycjami do organizowania pracy innych osób. Z kolei najmniejsze różnice dotyczą samooceny umiejętności interpersonalnych, obsługi urządzeń i biegłego posługiwania się językiem polskim.

Tab. 1. Różnice przeciętnych samoocen kompetencji przez respondentów z obszarów metropolitalnych i pozostałych obszarów

\begin{tabular}{|c|c|c|}
\hline Kategoria kompetencji & Różnica & Istotność \\
\hline Komputer & 0,273 & tak \\
\hline Organizowanie & 0,247 & tak \\
\hline Kierowanie & 0,208 & tak \\
\hline Artystyczne & 0,196 & tak \\
\hline Informacje & 0,188 & tak \\
\hline Obliczenia & 0,140 & tak \\
\hline Inicjatywa & 0,136 & tak \\
\hline Dyspozycyjność & 0,093 & tak \\
\hline Polski & 0,089 & tak \\
\hline Urządzenia & 0,082 & tak \\
\hline Kontakty & 0,077 & tak \\
\hline Sprawność & 0,000 & nie \\
\hline
\end{tabular}

Źródło: obliczenia własne na podstawie danych BKL 2010-2014.

W celu szczegółowego zilustrowania powiązań pomiędzy deklarowanym poziomem umiejętności w skali 1-5 oraz zamieszkiwaniem bądź nie w obszarze metropolitalnym posłużono się wykresami asocjacji (rys. 3), które sporządzono dla ośmiu kompetencji odznaczających się największymi różnicami. Układ prostokątów na wykresach potwierdza wcześniejsze spostrzeżenie o przewadze obszarów metropolitalnych nad resztą terytorium - odchylenia in plus liczebności zaobserwowanych od liczebności 
oczekiwanych, reprezentowane przez ciemniejsze prostokąty skierowane ku górze, mają miejsce dla wysokich wartości ocen w przypadku obszarów metropolitalnych oraz dla niskich wartości ocen dla pozostałych podregionów. Warto zauważyć, że kategoria środkowa (ocena 3) charakteryzuje się stosunkowo wysokimi liczebnościami oczekiwanymi, o czym świadczą szerokie podstawy prostokątów, ale raczej w niewielkim stopniu wnosi wkład w zróżnicowanie. Interesujące wnioski można wyciągnąć na podstawie wizualizacji dla czterech umiejętności o najwyższych różnicach w samoocenie (komputer, organizowanie, kierowanie, artystyczne), gdzie zwraca uwagę duża polaryzacja odpowiedzi, w szczególności najbardziej znaczące odchylenia dla najniższej kategorii (oceny 1) oraz kategorii najlepszych (tj. 4 i 5). Co ważne, ta prawidłowość ma miejsce dla tak kluczowej kompetencji, jaką jest wykorzystywanie technologii komunikacyjno-informacyjnych. Dla kompetencji dotyczących analizy informacji oraz wykonywania obliczeń odnotować można odmienne kształtowanie się odchyleń, których maksymalne wartości koncentrują się przy odpowiedziach znajdujących się bliżej środka skali (tj. 2 i 4), co wskazuje na mniejszy stopień polaryzacji.

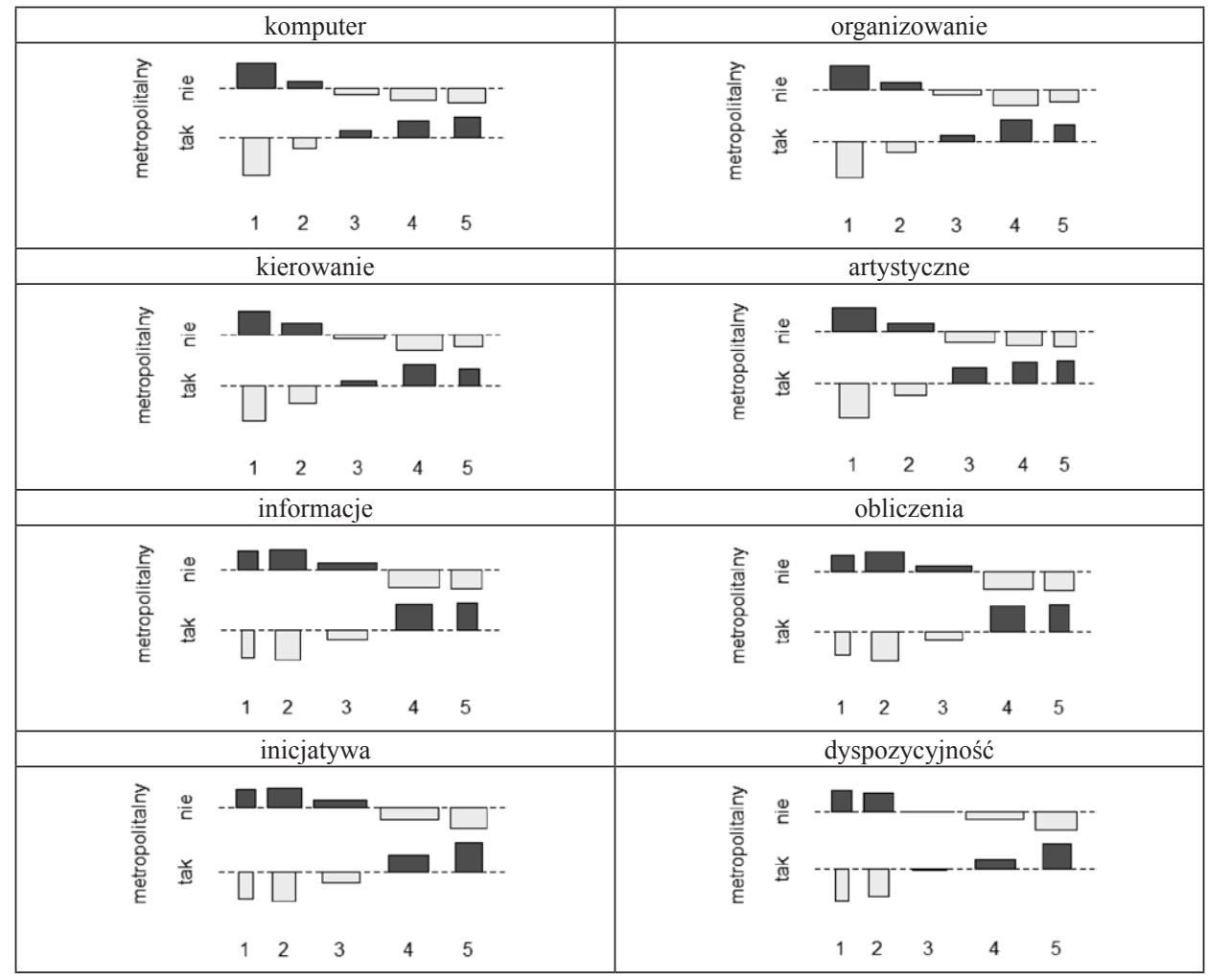

Rys. 3. Wykresy asocjacji dla poszczególnych kategorii samooceny kompetencji w skali 1-5 oraz miejsca zamieszkania w ujęciu obszary metropolitalne - pozostałe obszary 


\section{Ocena różnic w zakresie kapitału ludzkiego pomiędzy miastami centralnymi a pozostalą częścią obszarów metropolitalnych}

Drugą analizę przeprowadzono w celu porównania elementów kapitału ludzkiego wewnątrz obszarów metropolitalnych, tj. w podziale na ich centrum (duże miasto) oraz strefę zewnętrzną. Obliczono średnie wartości samooceny kompetencji przez respondentów reprezentujących miasta centralne oraz zamieszkujących przyległe obszary. Na poziomie istotności 0,001 zweryfikowano hipotezy o równości średnich. W tab. 2 zaprezentowano różnice w ocenie umiejętności w kolejności od największej do najmniejszej oraz wnioski z testowania różnic. Dla 11 z 12 badanych umiejętności różnice są istotne, a wyjątek stanowi sprawność fizyczna, dla której nie odnotowano znaczących rozbieżności. Wszystkie istotne różnice mają ten sam kierunek - samoocena kompetencji osób zamieszkujących miasta centralne przewyższa ewaluację dokonywaną przez osoby z obszarów peryferyjnych. Warto zauważyć, że na dwóch pierwszych pozycjach uporządkowania według największych różnic są te same kompetencje, co $\mathrm{w}$ tab. 1 , tj. umiejętność obsługi komputera oraz organizowanie i prowadzenie prac biurowych, ale rozdźwięk pomiędzy nimi jest zdecydowanie wyższy. Kolejne miejsca zajmują takie umiejętności, jak: analiza informacji, kierowanie innymi osobami oraz biegłość w języku polskim. Zestawienie zamykają dyspozycyjność oraz obsługa urządzeń technicznych.

Tab. 2. Różnice przeciętnych samoocen kompetencji przez respondentów z miast centralnych i pozostałych części obszarów metropolitalnych

\begin{tabular}{|c|c|c|}
\hline Kategoria kompetencji & Różnica & Istotność \\
\hline Komputer & 0,418 & tak \\
\hline Organizowanie & 0,300 & tak \\
\hline Informacje & 0,271 & tak \\
\hline Kierowanie & 0,262 & tak \\
\hline Polski & 0,250 & tak \\
\hline Inicjatywa & 0,216 & tak \\
\hline Artystyczne & 0,200 & tak \\
\hline Kontakty & 0,182 & tak \\
\hline Obliczenia & 0,168 & tak \\
\hline Dyspozycyjność & 0,153 & tak \\
\hline Urządzenia & 0,061 & tak \\
\hline Sprawność & $-0,015$ & nie \\
\hline
\end{tabular}

Źródło: obliczenia własne na podstawie danych BKL 2010-2014.

Wykresy asocjacji dla ośmiu kompetencji charakteryzujących się największymi różnicami przedstawia rys. 4. Uprzednio wskazana dominacja miast centralnych nad strefą zewnętrzną znajduje potwierdzenie w rozmieszczeniu i rozmiarze prostokątów reprezentujących poszczególne komórki tabel kontyngencji odpowiadające deklarowanemu poziomowi kompetencji w skali 1-5 oraz zamieszkiwaniem bądź nie 
w mieście centralnym. Istotne rozbieżności w samoocenie pojawiły się w przypadku umiejętności obsługi komputera i wykorzystania internetu - największe prostokąty występują dla wartości skrajnych (ocen 1 i 5), co świadczy o znaczącej polaryzacji w ocenie tego rodzaju umiejętności. Liczba mieszkańców miast centralnych oceniających swoje kompetencje w tym zakresie jako najwyższe w dużym stopniu przekracza oczekiwaną liczebność i vice versa - liczba mieszkańców stref zewnętrznych deklarujących najsłabsze umiejętności informatyczne jest niewspółmiernie wysoka. Układ prostokątów pozwala wskazać pewne wspólne wzorce odpowiedzi. W przypadku organizowania prac biurowych oraz zdolności kierowniczych środkowa kategoria (ocena 3) nie wykazuje znaczących odchyleń, w przeciwieństwie do kategorii bardziej skrajnych (1-2 oraz 4-5). Interesujące jest również nierównomierne umiejscowienie odchyleń w przypadku posługiwania się językiem polskim i umiejętności interpersonalnych (kontakty) - niewielkie znaczenie mają różnice dla odpowiedzi 4, a duże - odpowiedzi skrajnie pozytywne (5). Oczywiście ogólny schemat pozostaje niezmieniony - wyższe kompetencje to domena miast centralnych.

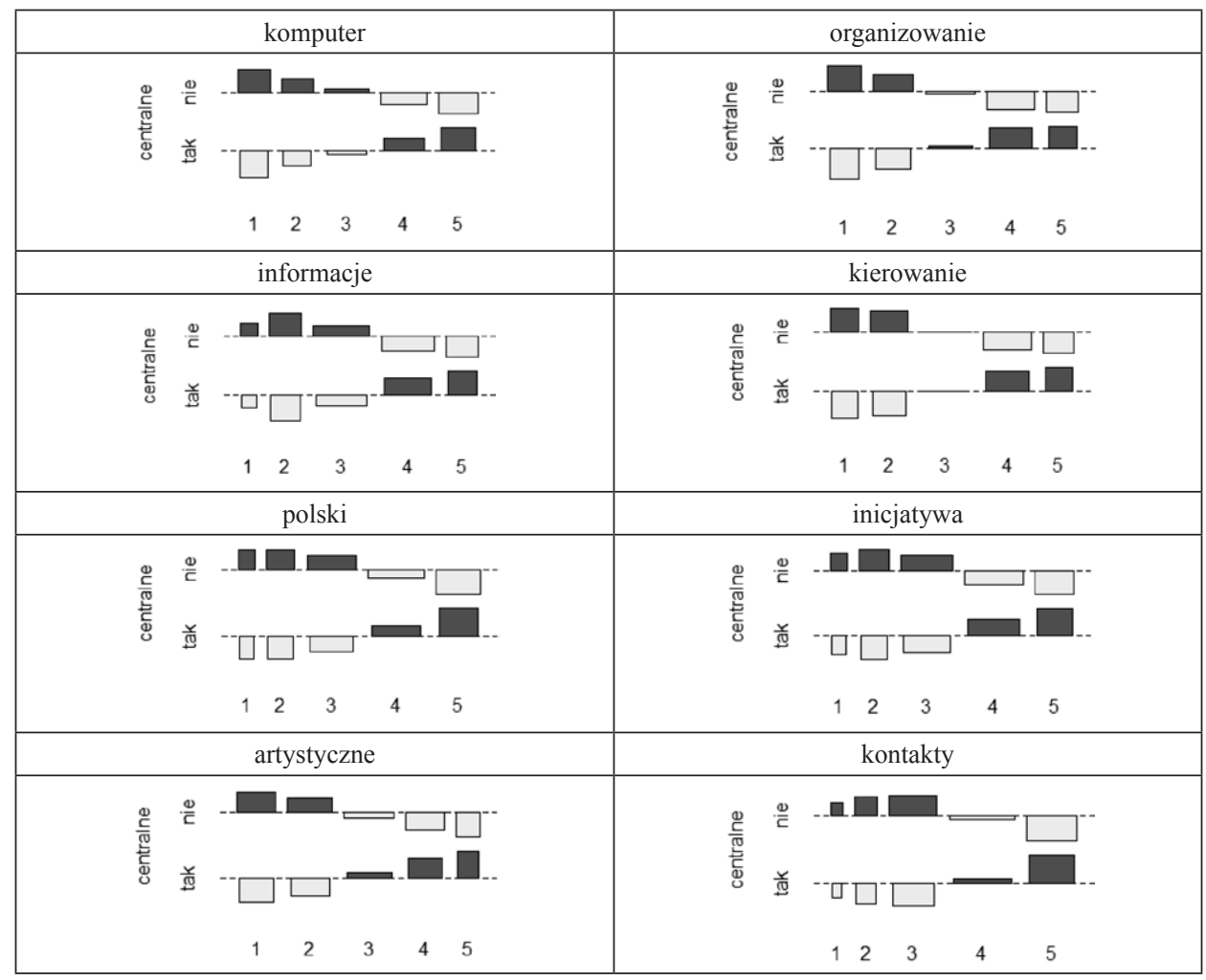

Rys. 4. Wykresy asocjacji dla poszczególnych kategorii samooceny kompetencji w skali 1-5 oraz miejsca zamieszkania w ujęciu miasta centralne - strefa zewnętrzna 


\section{Podsumowanie}

Przeprowadzona analiza pozwoliła zidentyfikować pewne prawidłowości w zakresie kształtowania się wybranych składowych kapitału ludzkiego w odniesieniu do istniejących w Polsce obszarów metropolitalnych. Otrzymane wyniki pozwalają na sformułowanie kilku zasadniczych wniosków. Po pierwsze, stwierdzono istnienie istotnych różnic w poziomie kompetencji mieszkańców obszarów metropolitalnych i pozostałych jednostek terytorialnych. Po drugie, analogiczną konkluzję można przedstawić, porównując deklarowane umiejętności osób żyjących w miastach centralnych i zamieszkujących strefę zewnętrzną obszaru metropolitalnego. Po trzecie, wykazano, że wzorce odpowiedzi dotyczących samooceny poszczególnych kompetencji nie są jednakowe. Trzeba mieć jednakże na uwadze, że wykonane badanie opiera się na osiągalnym materiale statystycznym dotyczącym samooceny kompetencji, a nie na wynikach zobiektywizowanego pomiaru z racji tego, że takowe nie są dostępne. Mimo tego ograniczenia można stwierdzić, że wyniki potwierdzają tendencję do przyciągania kapitału ludzkiego przez duże miasta i obszary do nich przyległe. Zwraca również uwagę fakt, że obszary metropolitalne wykazują znaczną niejednorodność ze względu na występowanie koncentracji osób o wysokich kompetencjach w miastach centralnych. Dla większości rozpatrywanych umiejętności różnice wewnątrz obszarów metropolitalnych były większe niż różnice zmierzone w odniesieniu do pozostałych jednostek terytorialnych. Na szczególną uwagę zasługuje fakt, że największe zróżnicowanie wystąpiło w przypadku umiejętności informatycznych, które zaliczane są do kompetencji kluczowych niezbędnych do funkcjonowania we współczesnym świecie, a ich większe zasoby w obszarach metropolitalnych, a zwłaszcza ich centrach, mogą stanowić newralgiczny czynnik dalszego rozwoju.

\section{Bibliografia}

Cohen A., On the graphical display of the significant components in a two-way contingency table, "Communications in Statistics - Theory and Methods" 1980, Vol. 9(10),

DOI: https://doi.org/10.1080/03610928008827940.

Danielewicz J., Zarządzanie obszarami metropolitalnymi wobec globalnych procesów urbanizacji, Wydawnictwo Uniwersytetu Łódzkiego, Łódź 2013.

Danielewicz J., Markowski T., Zarządzanie w obszarze metropolitalnym - podejście instytucjonalne, „Biuletyn PAN. Komitet Przestrzennego Zagospodarowania Kraju” 2008, nr 237.

Friendly M., Visualizing categorical data, SAS Institute Inc., Cary NC 2000.

Friendly M., Meyer D., Discrete Data Analysis with R: Visualization and Modeling Techniques for Categorical and Count Data, CRC Press, Boca Raton 2015.

Górniak J. (red.), Kompetencje Polaków a potrzeby polskiej gospodarki. Raport podsumowujący IV edycję badań BKL z 2013 r., PARP, Warszawa 2014.

Jabłoński Ł., Kapitał ludzki a konwergencja gospodarcza, C.H. Beck, Warszawa 2012.

Kryńska E., Kwiatkowski E., Podstawy wiedzy o rynku pracy, Wydawnictwo Uniwersytetu Łódzkiego, Łódź 2013. 
Lackowska M., Zarządzanie obszarami metropolitalnymi w Polsce. Między dobrowolnościa a imperatywem, Wydawnictwa Uniwersytetu Warszawskiego, Warszawa 2009.

Meyer D., Zeileis A., Hornik K., Visualizing independence using extended association plots, [w:] K. Hornik, F. Leisch, A. Zeileis (eds.), Proceedings of the $3^{\text {rd }}$ International Workshop on Distributed Statistical Computing, 2003, www.R-project.org/conferences/DSC-2003/Proceedings [dostęp: 26.06.2017].

Nowak M.J., Polityka przestrzenna w polskich obszarach metropolitalnych. Koncepcje planistyczne. Zakres prac planistycznych. Wydatki na planowanie przestrzenne, Wydawnictwa Fachowe CeDeWu, Warszawa 2010.

PARP, Bilans kapitału ludzkiego w Polsce. Badania ludności, 2013, https://bkl.parp.gov.pl/pobierz.html/ kwestionariusze_IV_2013.7z [dostęp: 25.06.2017].

Pasterz T., Kapitat ludzki, wiedza i innowacje jako czynniki wzmacniające funkcje metropolitalne miast wojewódzkich, na przykładzie Rzeszowa - stolicy regionu podkarpackiego, „Acta Universitatis Lodziensis. Folia Oeconomica" 2010, nr 246.

Pocztowski A., Zarządzanie zasobami ludzkimi. Strategie - procesy-metody, PWE, Warszawa 2003.

Unia Metropolii Polskich, Z atlasu UMP, 2013, www.metropolie.pl/wp-content/uploads/2013/09/Waga_ subregionow_w_rozwoju_wojewodztwa_Z_Atlasu-UMP1.pdf [dostęp: 26.06.2017].

\section{Polish Metropolitan Areas and Selected Components of Human Capital: Analysis Based on Self-Assessment of Competences}

The paper is focused on assessing the resources of selected human capital elements in regard with metropolitan areas. The analysis is conducted in two ways: a comparison is made between the level of competences declared by metropolitan residents and respondents from other territorial units as well as the differences within metropolitan areas are examined in the sense of confronting their central cities and the surrounding outer zones. The study is based on nationwide survey data and the quantitative approach is used - average results are compared and association plots are used to identify the largest deviations in contingency tables. The analysis leads to the conclusions that there are significant differences in the level of the competences and an advantageous situation in this regard occurs in the metropolitan areas.

\section{Polskie obszary metropolitalne a wybrane komponenty kapitału ludzkiego - analiza na podstawie samooceny kompetencji}

W artykule podjęto tematykę dotyczącą oceny zasobów wybranych elementów kapitału ludzkiego w odniesieniu do obszarów metropolitalnych. Analiza została przeprowadzona w dwóch ujęciach: dokonano porównania poziomu kompetencji deklarowanych przez mieszkańców obszarów metropolitalnych i respondentów z pozostałych jednostek terytorialnych oraz przeprowadzono ocenę różnic istniejących wewnątrz obszarów metropolitalnych w sensie zestawienia miast centralnych i otaczających je stref zewnętrznych. Badanie przeprowadzono na podstawie danych z ogólnopolskiego badania sondażowego, stosując ujęcie ilościowe - porównano przeciętne wyniki oraz zastosowano wykresy asocjacji w celu zidentyfikowania największych odchyleń w tabelach kontyngencji. Przeprowadzona analiza pozwoliła sformułować wnioski o występowaniu istotnych różnic w zasobach kompetencji i przewadze obszarów metropolitalnych w tym zakresie. 